\title{
A plant from the altiplano of Northern Chile Senecio nutans, inhibits the Vibrio cholerae pathogen
}

\author{
Adrian Paredes ${ }^{2 *}$, Yanett Leyton ${ }^{1}$, Carlos Riquelme ${ }^{1}$ and Glauco Morales ${ }^{2}$
}

\begin{abstract}
Background: In the altiplano of Northern Chile the plant Senecio nutans is habitually used as an infusion to relieve the effects of altitude sickness (locally known as "puna"). It is also used to alleviate the bronchitis, whooping cough, asthma, stomachache, tiredness and fever. The extreme conditions under which these plant grow and scientific data that shows the inhibiting potential of the essential oils of plants of the genus Senecio represents great potential in the study of their application to control pathogens like Vibrio Cholera.

Methods: The essential oil from aerial parts of $S$. nutans was isolated by hydrodistillation and the chemical composition characterized by GC-MS analyses. The antibacterial potential and determination of MIC value, was estimated in both micro and macro dilution method.

Results: The GC-MS analysis of essential oil of $S$. nutans showed the presence of methyl cinnamate (44.9\%), p-cymenol (27.2\%), and terpinen-4-ol (6.8\%), a-terpineol (4.1\%), t-cadinol (3.5\%), methyl hydrocinnamate (2.1\%), $\delta$-cadinene $(2.0 \%)$, p-cymene (1.9\%), $\gamma$-terpinene (1.8\%), a-cadinol (1.6\%), cis-sabinene hydrate (1.1\%), caryophyllene $(0.9 \%)$, $\beta$-pinene $(0.8 \%)$, and a-terpinene $(0.6 \%)$ as major components. Moreover, the oil of S. nutans exhibited an important antibacterial activity with a diameter of inhibition zone growth of $22 \mathrm{~mm}$ and the MIC value of $0.4 \mathrm{mg} /$ $\mathrm{mL}$ against pathogenic bacteria $V$. cholerae.
\end{abstract}

Conclusions: The results show for the first time the antibacterial activity of the essential oils of S. nutans against the $\mathrm{V}$. cholerae pathogen, an activity that can be applied as a preventive treatment against the action of pathogen.

Keywords: Chachacoma, Antimicrobial activities, Vibrio Cholerae, Senecio nutans, Essential oils

\section{Background}

The increasing resistance developed by microorganisms to treatment with antibiotics has affected both humans and the agricultural and aquacultural industry (Broszat and Grohmann 2014). The latter has intensified the search for new antimicrobials to control pathogenic agents. A natural source of antimicrobials agents is provided by plants (Fredes and Montenegro 2013). Essential (volatile) oils of herbs and their components, products from the secondary metabolism of a plant, are complex mixtures of various compounds, usually monoterpenes,

\footnotetext{
*Correspondence: adrian.paredes@uantof.cl

${ }^{2}$ Laboratorio Química Biológica, Instituto Antofagasta (IA), Universidad de Antofagasta, Av. Universidad de Antofagasta, 02800 Antofagasta, Chile Full list of author information is available at the end of the article
}

sesquiterpenes, phenylpropanes, low molecular weight aliphatic compounds, and others (Benites et al. 2011; Kahriman et al. 2011; Oladipupo and Adebola 2009). The biological activity of essential oils is centered on antimicrobial, anticancer, analgesic, antioxidant, antiinflammatory, and antithrombotic activities, (Adorjan and Buchbauer 2010; Bakkali et al. 2008). These properties make essential oils the raw materials in various fields such as cosmetics (perfumes and aromatherapy), food (spices), and pharmaceutical (phytotherapy) industries and have many applications in folk medicine (Adorjan and Buchbauer 2010; Citarasu 2010).

Senecio is one of the most widely spread genera in the world, with about 3000 species. In South America, Chile and Argentina have the largest numbers, with 
approximately 300 species each (Bolzan et al. 2007; Moreira-Muñoz and Muñoz-Schick 2007). From the chemical standpoint this genus is characterized by producing pyrrolizidine alkaloids, and its species are the main producers of these compounds with well-known hepatotoxic and carcinogenic activity, but not all Senecio species produce these kinds of compounds (Bolzan et al. 2007; Echeverría and Niemeyer 2012). Other constituents of interest from Senecio are diterpenes, sesquiterpenes with eremophilane, cacalol, bisabolane, silphinene, caryophillane, humulane, germacrane, triterpenes, $p$-hydroxyacetophenones derivatives, benzofurane and flavonoids (Morales et al. 1986, 1996, 2000; Portero et al. 2013; Ruiz-Vasquez et al. 2015; Wang et al. 2013), and they are also characterized by the presence of polyfructanes and sesquiterpene lactones that are attributed antimicrobial activity (Albayrak et al. 2014; Yanga et al. 2011).

The leaves of Senecio nutans are used in the Andes of Northern Chile as an infusion to lower blood pressure counteract the effects of altitude sickness, locally known as "puna." Other uses of this species are to alleviate the discomfort caused by cold, bronchitis, whooping cough, asthma, stomachache, tiredness, and fever. Sometimes it is also used as a condiment (Carod-Artal and VázquezCabrera 2007; Giberti 1983; Marcía et al. 2005; Villagrán and Castro 2003; Villagrán et al. 2003; Zardini 1984). Species of the genus Senecio possess the largest medicinal value for these Andes communities, and studies on the biological activities attributed to them are scarce.

The bacteria Vibrio cholerae can be found free or forming biofilms, in association with corals, fish, molluscs, algae, shrimp, and zooplankton, and even in the intestinal contents of these organisms (Leyton and Riquelme 2008). The pathogen $V$. cholerae is the agent that causes the gastrointestinal disease called cholera, which can expand rapidly as an epidemic and/or pandemic through the ingestion of contaminated water and/or food (Mala et al. 2013). It is a Gram-negative and there are around 200 recognized $\mathrm{O}$ serotypes, but only serotypes $\mathrm{O} 1$ and O139 are associated with serious cases of cholera (Bauman 2012; Hendriksen et al. 2011), manifested by symptoms such as gastroenteritis, skin infections, septicemia, and even death in the case of immunosuppressed patients (Liu et al. 2014; World Health Organization 2014).

In view of the need to control the diseases caused by the pathogenic bacteria $V$. cholerae, and based on the scientific background that shows the inhibiting potential of the essential oil extracts of plants of the genus Senecio, the present study had the purpose of evaluating the inhibiting activity of the essential oils of $S$. nutans against the $V$. cholerae pathogen as a future potential application of the components of these extracts to control this pathogen.

\section{Methods \\ Collection of botanical samples}

The leaves of $S$. nutans were collected from plants growing in a natural population in nearby the locality of Toconce $\left(22^{\circ} 15^{\prime} 11.16^{\prime \prime} \mathrm{S}, 68^{\circ} 5^{\prime} 44.68^{\prime \prime} \mathrm{W}\right.$, at $\left.3788 \mathrm{~m} . \mathrm{a} . \mathrm{s} . \mathrm{l}.\right)$ in April of 2014 at II Región of Antofagasta, Chile. The specimen was authenticated by Dr. Roberto Rodríguez, Departamento de Botánica, Facultad de Ciencias Naturales y Oceanográficas, Universidad de Concepción, Concepción, Chile. A sample was kept for the herbarium collection, under register CONC 139.929.

\section{Isolation of essential oil (EO)}

The essential oils were obtained from $300 \mathrm{~g}$ of ground fresh plants by hydrodistillation during $3 \mathrm{~h}$ in a Clevenger-type apparatus, and was collected from the aqueous phase using ethyl ether extraction. The oil was sealed in a glass vial and refrigerated at $4{ }^{\circ} \mathrm{C}$ to avoid its decomposition by light or heat. The yield of oil was calculated in terms of the obtained oil mass and plant mass used.

\section{Gas chromatography: mass spectrometry}

The determination and quantification of the composition of the essential oil was performed by gas chromatography coupled with mass spectrometry (GC-MS) using an Agilent $5973 \mathrm{~N}$ GC/MS system, with a fused silica capillary column $(30 \mathrm{~m} \times 0.25 \mathrm{~mm}$ coated with DB-5, film thickness $0.25 \mu \mathrm{m}$ ), the flow rate was $1 \mathrm{~mL} / \mathrm{min}$ with helium carrier gas at $7 \mathrm{psi}$, injector port at a temperature of $250{ }^{\circ} \mathrm{C}$ and a split ratio of $1: 30$ and oven temperature programmed from 60 to $280{ }^{\circ} \mathrm{C}$ at $2{ }^{\circ} \mathrm{C}$ per min, injection of $2 \mu \mathrm{L}$ of sample ( $10 \% n$-hexane).

The mass spectrometer conditions were: electron impact mode (EI) $70 \mathrm{eV}$, ion source at $230{ }^{\circ} \mathrm{C}$, quadrupole analyzer $150{ }^{\circ} \mathrm{C}$, a scanning range of $\mathrm{m} / z=35-450$. An HP MSD Enhanced ChemStation Software module controlled all parameter. Identification of components were made by comparing retention indices (RI) according to the Wiley Library and NIST 2000 database.

\section{Getting the pathogenic strain}

The pathogenic strain Vibrio cholerae tor 1 was obtained from the strain collection of the Laboratorio Mesocosmos Marino, Centro de Bioinnovación de Antofagasta, Facultad de Ciencias del Mar y Recursos Biológicos, Universidad de Antofagasta. The strain was kept in a cryopearl collection and in culture plates with Trypticase soy agar, TSA (Oxoid Ltd, Basingstoke, Hampshire, England) under axenic conditions at $20 \pm 1{ }^{\circ} \mathrm{C}$. 


\section{Antibiogram of essential oil from $S$. nutans against $V$. cholera}

Antimicrobial activity testing was carried out using a disc-diffusion method. Petri dishes were prepared using Mueller-Hinton agar (38 g/L with addition of $2 \% \mathrm{NaCl})$. A $100 \mu \mathrm{L}$ aliquot of the pathogenic bacteria was used to inoculate a Trypticase soy culture broth (TSB), incubating at $20{ }^{\circ} \mathrm{C}$ during $12 \mathrm{~h}$. Sterile filter paper discs of $6 \mathrm{~mm}$ in diameter were impregnated directly with $10 \mu \mathrm{L}$ of the oil (which correspond to $9.28 \mathrm{mg}$ of essential oils S. nutans). A $100 \mu \mathrm{L}$ sample was removed from the $12-\mathrm{h}$ culture and it was streaked on the surface of the solid medium using a sterile loop. The disc with the product was then placed on the surface seeded with the pathogen. The control antibiotics used were Chloramphenicol (CL) (30 $\mu \mathrm{g} /$ disc), Streptomycin (S) $(10 \mu \mathrm{g} / \mathrm{disc})$, Sulfamethoxazol/Trimetoprim (SXT) $(25 \mu \mathrm{g} /$ disc), and Cefotaxime (CTX) $(30 \mu \mathrm{g} / \mathrm{disc})$. Each treatment was performed in triplicate. The plates were incubated at $37^{\circ} \mathrm{C}$ during $24 \mathrm{~h}$. A halo $>5 \mathrm{~mm}$ around the filter caused by the absence of bacterial growth was considered as inhibition.

\section{Identification of the inhibiting concentration of S. nutans}

The minimum inhibitory concentration (MIC) was determined according to the micro-dilution in broth method described by (Rejiniemon et al. 2014; Wiegand et al. 2008), with the following modifications: (a) sterile 96-well plates were used, $\left(12 \mathrm{~mm} \times 8 \mathrm{~mm}\right.$. Costar ${ }^{\odot}$, 96 Well Cell Culture Cluster, Corning Incorporated); (B) seawater, previously filtered to $0.2 \mu \mathrm{m}$ and kept at $4{ }^{\circ} \mathrm{C}$, was used as the test medium; $(\mathrm{C})$ the essential oil concentration range studied was $0.05-12.8 \mathrm{mg} / \mathrm{mL}$, obtained from three stock solutions in ethanol: Stock Solution A-50 mg/ $\mathrm{mL}(0.075 \mathrm{~g}$ of sample in $1.5 \mathrm{~mL}$ of ethanol); Stock Solution B-12.8 mg/mL $(89.6 \mu \mathrm{L}$ of Stock Solution A were diluted in $260 \mu \mathrm{L}$ of solvent); Stock Solution C-0.8 mg/ mL: $(31.25 \mu \mathrm{L}$ of Stock Solution B were diluted in $469 \mu \mathrm{L}$ of solvent. Then the desired concentrations were placed in each well considering a final volume of $200 \mu \mathrm{L}$.

The bacterial inoculum was added at a concentration of $1 \times 10^{8} \mathrm{CFU} / \mathrm{mL}$, obtained from an 18 -h culture in Trypticase soy broth. Each plate was incubated at $37{ }^{\circ} \mathrm{C}$ for $24 \mathrm{~h}$. The controls were seawater (medium in which the bacteria were diluted and inoculated in each well), and ethanol (solvent used to dilute the essential oil), with one control for each sample concentration. The resulting turbidity was observed and MIC value was determined to be where growth was no longer visible by assessment of turbidity by optical density reading at $620 \mathrm{~nm}$ with a Tecan $^{\odot}$ Sunrise 96 well Microplate Readers. All essential oil concentrations and controls used were analyzed in triplicate.
Bacterial growth in the presence of S. nutans essential oil Aliquots of 10, 30 and $60 \mu \mathrm{L}$ of $S$. nutans essential oil were added directly to test tubes, getting concentrations of 1 , 3 and $6 \mathrm{mg} / \mathrm{mL}$. Bacteria without essential oil (CT), and bacteria plus Chloramphenicol (CT CL) in concentration of $1 \mathrm{mg} / \mathrm{mL}$ were used as positive control. From an 18-h culture of the bacteria in TSB, an initial concentration of $1 \times 10^{3} \mathrm{CFU} / \mathrm{mL}$ was inoculated. The treatments and control were made in triplicate. Bacterial growth inhibition was evaluated at $48 \mathrm{~h}$ of culture by counting viable bacteria in TSA plates that were incubated at $37{ }^{\circ} \mathrm{C}$ during $48 \mathrm{~h}$ and the bacterial count was expressed in colony forming units per milliliter $(\mathrm{CFU} / \mathrm{mL})$.

\section{Statistical analysis}

The results were reported as mean \pm standard error. One way ANOVA and Tukey post Hoc multiple comparison test were used to analyze data with the sofware GraphPad Prism, version 5.0 for Mac OS X. The level of significance was set at $P<0.05$.

\section{Results}

Components of S. nutans essential oil

The yield of essential oil from S. nutans was $0.37 \%$ (w/w based on fresh plants). The oil has a yellow color and a strong smell. The composition obtained by GC-MS (Table 1) showed that the main compounds were: methyl cinnamate (44.9\%), p-cymenol (27.2\%), terpinen-4-ol (6.8 \%), $\alpha$-terpineol (4.1\%), $t$-cadinol (3.5\%), methyl hydrocinnamate $(2.1 \%), \delta$-cadinene $(2.0 \%), p$-cymene (1.9\%), $\gamma$-terpinene (1.8\%), $\alpha$-cadinol (1.6\%), cis-sabinene hydrate $(1.1 \%)$, caryophyllene $(0.9 \%), \beta$-pinene $(0.8 \%)$, and $\alpha$-terpinene $(0.6 \%)$. These compounds represent approximately $98.7 \%$ of the composition of the essential oil. The remaining $1.3 \%$ of the compounds corresponded to those with lower abundance of $0.5 \%$, as $\alpha$-phelandrene $(0.4 \%)$, trans-piperitol $(0.4 \%)$, linalool $(0.3 \%), \alpha$-humulene $(0.1 \%)$ and thymol $(0.1 \%)$.

\section{Antibiograms of S. nutans essential oil against $V$. cholerae} The essential oil of $S$. nutans showed a 22-mm diameter inhibition halo against the pathogenic bacteria $V$. cholerae (tor1) (Fig. 1), while the controls showed Chloramphenicol $30 \mathrm{~mm}$, streptomycin $11 \mathrm{~mm}$, sulfamethoxazol/trimetoprim $31 \mathrm{~mm}$, and cefotaxime $20 \mathrm{~mm}$ diameter halos. The inhibition halo of $S$. nutans remained for 7 days, and growth appeared in the inhibition zone after that period. The inhibiting activity shown by the essential oil of $S$. nutans had a similar diameter to that shown by the control antibiotic cefotaxime $(P>0.05)$ which had a $20 \mathrm{~mm}$ diameter halo. Additionally, the essential oil showed a significantly greater inhibition $(P<0.05)$ than 
Table 1 Percentage of chemical composition of the essential oil from the aerials part of $S$. nutans

\begin{tabular}{|c|c|c|c|c|}
\hline No & Components $^{\mathrm{a}}$ & $\mathbf{R} \mathbf{I}^{\mathbf{b}}$ & $\%^{c}$ & $\begin{array}{l}\text { Methods of identi- } \\
\text { fication }^{\mathrm{d}}\end{array}$ \\
\hline 1 & $\beta$-pinene & 980 & 0.8 & $M S, R I$ \\
\hline 2 & a-phellandrene & 1006 & 0.4 & $M S, R I$ \\
\hline 3 & a-terpinene & 1018 & 0.6 & $M S, R I$ \\
\hline 4 & p-cymene & 1026 & 1.9 & $M S, R I$ \\
\hline 5 & cis-sabinene hydrate & 1068 & 1.1 & $M S, R I$ \\
\hline 6 & $\gamma$-terpinene & 1070 & 1.8 & $M S, R I$ \\
\hline 7 & linalool & 1099 & 0.3 & MS, RI \\
\hline 8 & terpinen-4-ol & 1182 & 6.8 & MS, RI \\
\hline 9 & p-cymenol & 1187 & 27.2 & MS, RI \\
\hline 10 & a-terpineol & 1194 & 4.1 & MS, RI \\
\hline 11 & trans-piperitol & 1206 & 0.4 & $M S, R I$ \\
\hline 12 & methyl hydrocinnamate & 1281 & 2.1 & $M S, R I$ \\
\hline 13 & thymol & 1290 & 0.1 & MS, RI \\
\hline 14 & methyl cinnamate & 1372 & 44.9 & MS, RI \\
\hline 15 & caryophyllene & 1410 & 0.9 & MS, RI \\
\hline 16 & a-humulene & 1463 & 0.1 & $M S, R I$ \\
\hline 17 & $\delta$-cadinene & 1517 & 2.0 & $M S, R I$ \\
\hline 18 & $t$-cadinol & 1625 & 3.5 & $M S, R I$ \\
\hline \multirow[t]{8}{*}{19} & a-cadinol & 1670 & 1.6 & $M S, R l$ \\
\hline & Total & & 100 & \\
\hline & $\begin{array}{l}\text { Monoterpenes hydrocar- } \\
\text { bons }\end{array}$ & & 21.1 & \\
\hline & $\begin{array}{l}\text { Oxygenated monoter- } \\
\text { penes }\end{array}$ & & 26.3 & \\
\hline & $\begin{array}{l}\text { Sesquiterpenes hydro- } \\
\text { carbons }\end{array}$ & & 15.8 & \\
\hline & $\begin{array}{l}\text { Oxygenated sesquiter- } \\
\text { penes }\end{array}$ & & 10.5 & \\
\hline & Aromatic hydrocarbon & & 5.3 & \\
\hline & $\begin{array}{l}\text { Oxygenated aromatic } \\
\text { hydrocarbon }\end{array}$ & & 21.0 & \\
\hline
\end{tabular}

a Compounds presented according to the elution order in the column DB5

${ }^{\mathrm{b}}$ Retention Index relative on the DB5 column

c Percentage based on FID peak area normalization

${ }^{d}$ MS: compounds were tentatively identified by comparison with mass spectra data (MS) obtained from NIST/EPA/NIH and Wiley library; RI: confirmed by comparison with kovat's index on DB-5 column

the control streptomycin, which had an $11 \mathrm{~mm}$ diameter halo (Fig. 2).

\section{Inhibiting concentration of $S$. nutans}

The results in multi-well plates showed that when the bacterial pathogen was exposed to the essential oil of S. nutans, its growth was inhibited during the first $24 \mathrm{~h}$ of culture in all the treatments, showing significant differences at all concentrations with respect to the control $(P<0.05)$ confirming the antimicrobial property. Additionally, it was observed that the most effective

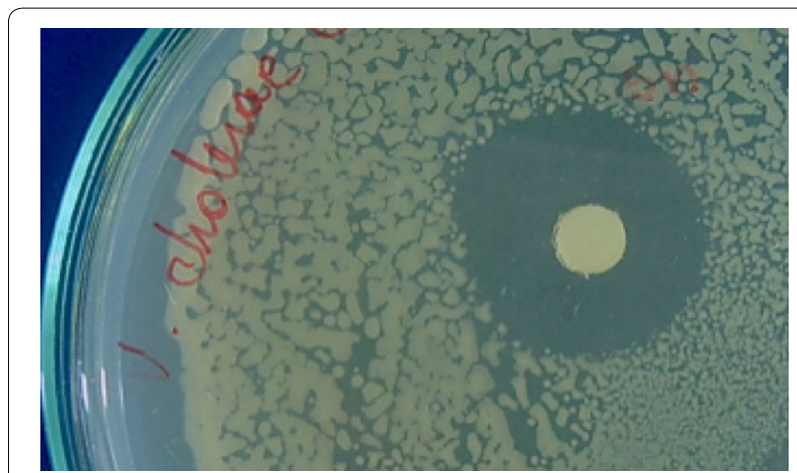

Fig. 1 Representative image of antibiograms of the essential oil (10 $\mu \mathrm{L}$ ) of $S$. nutans against $V$. cholerae pathogen by disc diffusion method

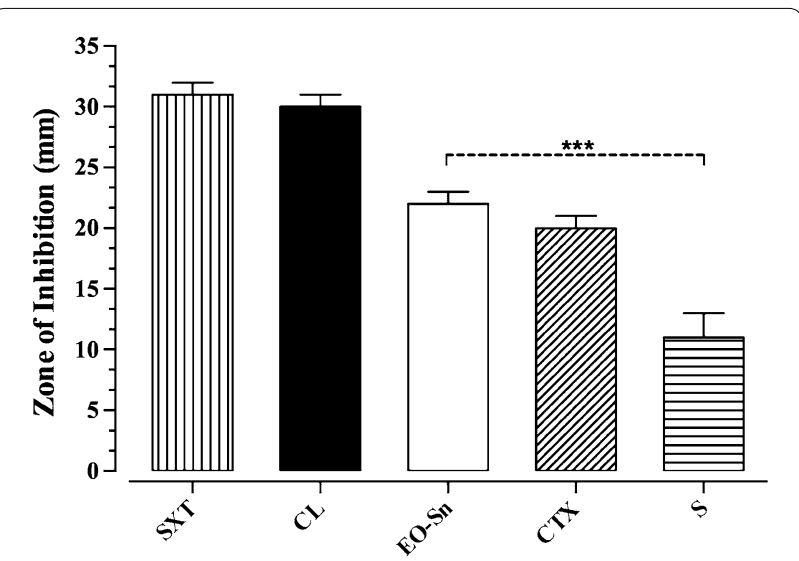

Fig. 2 Inhibitions zones ( $\mathrm{mm}$ ) of essential oil of S. nutans and antibiotic used as control. Data represent the means and standard error of the means $(n=3)$. The symbol *** shows significant differences $(P<0.05)$ respect to the control antibiotic Streptomycin $(S)(10 \mu \mathrm{g} /$ disc). The others antibiotics used were: Chloramphenicol (CL) $(30 \mu \mathrm{gg} /$ disc), Sulfamethoxazol/Trimetoprim (SXT) $(25 \mu \mathrm{g} /$ disc), and Cefotaxime (CTX) $(30 \mu \mathrm{g} / \mathrm{disc})$

concentrations of the essential oil of $S$. nutans for inhibiting Gram-negative bacteria $V$. cholerae, are in the range of concentrations of $0.05-0.4 \mathrm{mg} / \mathrm{mL}$, showing no significant difference between them $(P>0.05)$. The MIC value for the essential oil of $S$. nutans was $0.4 \mathrm{mg} / \mathrm{mL}$, this value showed no significant differences with respect to control that contained only the essential oil $(P>0.05)$, showing a clear inhibition of the growth of the bacteria (Fig. 3).

Bacterial growth in the presence of essential oil of $S$. nutans Bacterial growth in the presence of three essential oil concentrations of 1,3 and $6 \mathrm{mg} / \mathrm{mL}$ was evaluated. The growth was measured in $\mathrm{CFU} / \mathrm{mL}$ of the pathogenic bacteria in the presence of the essential oil (Fig. 4). The results showed that the three concentrations showed 


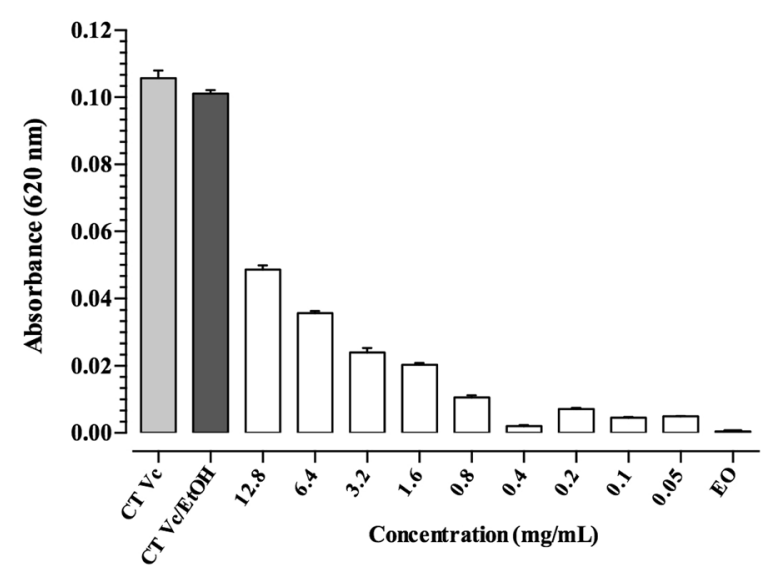

Fig. 3 Inhibitory bacterial concentration by essential oil of S. nutans. The bars represent the means and standard error $(n=3)$. CT (bacteria without essential oil), CT/EtOH (bacteria plus ethanol used to dissolve the essential oil) and EO (the essential oil of $S$. nutans in solution without bacteria as control)

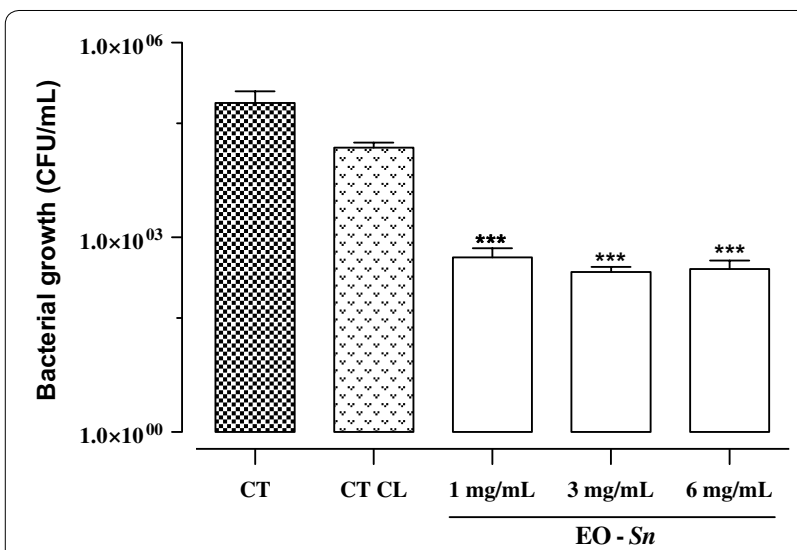

Fig. 4 Bacterial growth in the presence of essential oil of S. nutans. $\mathrm{CT}$ (untreated bacteria); CT CL (bacteria treated with Chloramphenicol (1 mg/mL); 1, 3 and 6 (bacteria treated with 1, 3 and $6 \mathrm{mg} / \mathrm{mL}$ of essential oil). The symbol *** shows significant differences $(P<0.05)$ respect to the controls (CT and $C T C L$ ). Data represent the means and standard error of the means $(n=3)$

inhibition of the pathogen's growth with significant differences with respect to the controls $(P<0.05)$. The greatest inhibition was seen with $6 \mathrm{mg} / \mathrm{mL}$, yielding a count of $2.5 \times 10^{2} \mathrm{CFU} / \mathrm{mL}$, followed by $3 \mathrm{mg} /$ $\mathrm{mL}$ with a count of $3.0 \times 10^{2} \mathrm{CFU} / \mathrm{mL}$, and $1 \mathrm{mg} /$ $\mathrm{mL}$ with a count of $5.0 \times 10^{2} \mathrm{CFU} / \mathrm{mL}$. The statistical analysis showed no significant differences $(P>0.05)$ between the antibacterial activities of these three concentrations of essential oil. The controls yielded the following results: CT $1.2 \times 10^{5} \mathrm{CFU} / \mathrm{mL}$ and CT CL $2.7 \times 10^{4} \mathrm{CFU} / \mathrm{mL}$.

\section{Discussion}

In the present study, the essential oil of $S$. nutans show a similar composition and a higher yield than described by Belaunde et al. (2007), De Feo et al. (2003). The differences in the composition of the essential oils of $S$. nutans, can be attributed to the chemotype variation, influenced by the geographic location, seasonal and climatic conditions and high levels of ultraviolet radiation in the desert regions where it inhabits this species (Reyes-Jurado et al. 2014). Analyses GC-MS identified a total of 19 components with one of the most abundant being methyl cinnamate (44.9\%) followed by $p$-cymenol $(27.2 \%)$. These two components together represent approximately the $72 \%$ of the total composition.

The essential oil of $S$. atacamensis, another species of Senecio that grows in the north of Chile, has been attributed antimicrobial properties against human pathogens by disc diffusion and dilution tests. The most abundant monoterpenes were $\alpha$-terpinene, $\alpha$-phellandrene, and $p$-cymene (Benites et al. 2011), which differ from the main components of $S$. nutans.

The inhibitory activity of the essential oil can be attributed to the monoterpene hydrocarbons that have been reported as the main components of the essential oils of various species of the genus Senecio (Kahriman et al. 2011). Some authors state that oils containing high percentages of monoterpene compounds ( $\alpha$-terpinene, $\alpha$-phellandrene, $p$-cymene, sabinene) have significant antimicrobial properties (Benites et al. 2011). On the other hand, the antimicrobial activity of the essential oils is attributed to the presence of terpenoids, followed by those that contain alcohol groups, those that have aldehyde groups, and finally those that contain ketone groups (Yanga et al. 2011). The combination of these compounds present in the essential oils can act collectively, causing antibacterial activity by synergistic effect. In other cases, an antagonistic effect had been observed in the components of essential oils, significantly reducing it's activity (Bassolé and Juliani 2012). The mechanism of the antibacterial action of the essential oils, mainly that of the terpenoids, is associated with the bacterial cell membrane, whose permeability to small ions increases, affecting its structural stability, destabilizing the packing of the lipidic bilayer, and causing the death of the bacterial cell. For example, it been described that terpinen-4-ol and $\alpha$-terpineol induced $\mathrm{K}^{+}$leakage from bacterial cells in different concentration, being more active at lower concentration terpinen-4-ol. The mode of antimicrobial action of this compound is attributed to the general characteristic of oxygenated terpenes and their ability to cause membrane permeability, $\mathrm{K}^{+}$leakage and reduction of membrane potential, collapsing of the proton pump, 
and depletion of the ATP pool (Reyes-Jurado et al. 2014). The compounds $\alpha$-terpineol and terpinen-4-ol, which are present in different proportions in the essential oil of $S$. nutans, could explain in part the mechanism of action on pathogenic bacteria of $V$. cholerae.

\section{Conclusions}

The results show for the first time the antibacterial activity of the essential oil of $S$. nutans against the $V$. cholerae pathogen, which represents a great applicability to preventive treatments of pathogens in aquacultural systems. This research opens the way for many new studies, such as those aimed in gaining essential oils of $S$. nutans in greater volumes, confirming the activity of the product in cultures of contaminated organisms, and evaluating whether the antibacterial activity has a direct relation with a specific predominant compound or a synergy of products that compose the essential oil. Compared to artificial chemicals or synthetic additives, essential oils have been recognized as effective decontaminants against various pathogens without adverse effect to human health (Tongnuanchan and Benjakul 2014; Wang et al. 2015). Additionally, the drugs of natural origin represent an interesting approach to limiting the appearance and propagation of hard to treat microorganisms. Moreover, the use of oils from plants from the altiplano that grow under extreme conditions is an interesting field and scarcely studied. These studies may have direct application in aquaculture, agriculture and phytotherapy, which has a high impulse at national level. The use of essential oils has certain advantages associated with a: reduced genotoxicity (even after prolonged used), the ability to act on multiple cellular targets, low cost for the productions and the most important, a less toxicity.

\section{Authors' contributions}

AP and GM carried out the collection of plant samples, isolation of essential oils and interpretation of GC-MS analysis. YL and CR carried out all antimicrobial proof and the analysis of the data. AP and YL wrote the manuscript. All authors read and approved the final manuscript.

\section{Author details \\ ${ }^{1}$ Laboratorio Mesocosmos Marino, Centro de Bioinnovación de Antofagasta (CBIA), Departamento de Biotecnología, Facultad de Ciencias del Mar y Recursos Biológicos, Universidad de Antofagasta, Av. Universidad de Antofa- gasta, 02800 Antofagasta, Chile. ${ }^{2}$ Laboratorio Química Biológica, Instituto Antofagasta (IA), Universidad de Antofagasta, Av. Universidad de Antofagasta, 02800 Antofagasta, Chile.}

\section{Acknowledgements}

Financial support under FONDEF MR10l1003, D10l1050, FIC-R (II Región)_FIA Grant EST 2010-0157 and VIU-FONDEF 12005 projects is gratefully acknowledged. The authors also thank Pilar Moyano for her collaboration in the practical activities.

\section{Competing interests}

The authors declare that they have no competing interests.
Received: 18 November 2015 Accepted: 5 October 2016

Published online: 13 October 2016

\section{References}

Adorjan B, Buchbauer G (2010) Biological properties of essential oils: an updated review. Flavour Fragr J 25:407-426

Albayrak S, Aksoy A, Yurtseven L, Yasar A (2014) A comparative study on phenolic components and biological activity of some Senecio species in Turkey. J Pharm Pharmacol 66:1631-1640

Bakkali F, Averbeck S, Averbeck D, Idaomar M (2008) Biological effects of essential oils: a review. Food Chem Toxicol 46:446-475

Bassolé H, Juliani R (2012) Essential oils in combination and their antimicrobial properties. Molecules 17:3989-4006

Bauman RW (2012) Microbial diseases of the digestive system. Microbiology with diseases by body system, 4th edn. Pearson, Kuala Lumpur

Belaunde AJ, Sandoval JG, De Martino L, Senatore F, De Feo V (2007) Chemical composition and antibacterial activity of Senecio nutans essential oil. J Essent Oil Bear Plants 10:332-338

Benites J, Bravo F, Rojas M, Fuentes R, Moiteiro C, Venãncio F (2011) Composition and antimicrobial screening of the essential oils from the leaves and stems of Senecio atacamensis Phil. from Chile. J Chil Chem Soc $56: 712-714$

Bolzan A, Silva C, Francescato L, Murari A, Silva G, Heldwein C, Heinzmann B (2007) Espécies de senecio na medicina popular da América Latina e toxicidade relacionada a sua utilizacao. Lat Am J Pharm 26:619-625

Broszat M, Grohmann E (2014) Spread of antibiotic resistance in the environment: impact on human health. In: Malik A, Grohmann E, Akhtar R (eds) Environmental deterioration and human health. Springer, Netherlands, pp 125-162

Carod-Artal F, Vázquez-Cabrera C (2007) An anthropological study about headache and migraine in native cultures from Central and South America. Headache 47:834-841

Citarasu T (2010) Herbal biomedicines: a new opportunity for aquaculture industry. Aquac Int 18:403-414

De Feo V, Urrunaga-Soria E, Urrunaga-Soria R, Senatore F (2003) Chemical composition of essential oils of Senecio nutans Sch. Bip. (Asteraceae). Flavour Fragr J 18:234-236

Echeverría J, Niemeyer NH (2012) Alkaloids from the native flora of Chile: a review. Bol Latinoam Caribe Plant Med Aromat 11:291-305

Fredes C, Montenegro G (2013) Chilean plants as a source of polyphenols. In: Céspedes CLS, Sampietro DA, Seigler DS, Rai M (eds) Natural antioxidants and biocides from wild medicinal plants. Cabi, London, UK, pp 116-136

Giberti G (1983) Herbal folk medicine in northwestern Argentina: compositae. J Ethnopharmacol 7:321-341

Hendriksen RS et al (2011) Population genetics of Vibrio cholerae from Nepal in 2010: evidence on the origin of the haitian outbreak. mBio 2(4):e00157-11

Kahriman N, Tosum G, Terzioglu S, SI Karaoglu, Yaylı N (2011) Chemical composition and antimicrobial activity of the essential oils from the flower, leaf, and stem of Senecio pandurifolius. Rec Nat Prod 5:82-91

Leyton Y, Riquelme C (2008) Vibrios en los sistemas marinos costeros. Rev Biol Mar Oceanogr 43:441-456

Liu J, Winstead-Derlega C, Houpt E, Heidkamp R, Pape J, Dillingham R (2014) Pre-earthquake non-epidemic Vibrio cholerae in Haiti. J Infect Dev Ctries 8:120-122

Mala E, Oberoi A, Alexander VS (2013) Vibrio isolates from cases of acute diarrhea and their antimicrobial susceptibility pattern in a tertiary care hospital. Int J Basic Appl Sci 3(1):35-37

Marcía M, García E, Vidaurre P (2005) An ethnobotanical survey of medicinal plants commercialized in the markets of La Paz and El Alto, Bolivia. J Ethnopharmacol 97:337-350

Morales G, Borquez J, Loyola LA (1996) A monoterpenoid and p-hydroxyacetophenone derivatives from Senecio species of the north of Chile. Bol Soc Chil Quim 41:159-166

Morales G, Bórquez J, Mancilla A, Pedreros S, Loyola LA (1986) An eremophilanolide from Senecio rosmarinus. Pythochemistry 25:2412-2413 
Morales G, Sierra P, Loyola LA, Borquez J (2000) A new eremophilanolide from Senecio atacamensis. Bol Soc Chil Quim 45:601-604

Moreira-Muñoz A, Muñoz-Schick M (2007) Classification, diversity, and distribution of Chilean Asteraceae: implications for biogeography and conservation. Divers Distrib 13:818-828

Oladipupo LA, Adebola OO (2009) Chemical composition of the essential oils of the flowers, leaves and stems of two Senecio polyanthemoides Sch. Bip. samples from South Africa. Molecules 14:2077-2086

Portero AG, González-Coloma A, Reina M, Díaz CE (2013) Plant-defensive sesquiterpenoids from Senecio species with biopesticide potential. Phytochem Rev 11:391-403. doi:10.1007/s11101-013-9279-3

Rejiniemon TS et al (2014) In-vitro antimicrobial, antibiofilm, cytotoxic, antifeedant and larvicidal properties of novel quinone isolated from Aegle marmelos (Linn.) Correa. Ann Clin Microbiol Antimicrob 13(1):1

Reyes-Jurado F, Franco-Vega A, Ramírez-Corona N, Palou E, López-Malo A

(2014) Essential oils: antimicrobial activities, extraction methods, and their modeling. Food Eng Rev 7:275-297

Ruiz-Vasquez L et al (2015) Sesquiterpenes, flavonoids, shikimic acid derivatives and pyrrolizidine alkaloids from Senecio kingii Hook. Phytochemistry 117:245-253

Tongnuanchan P, Benjakul S (2014) Essential oils: extraction, bioactivities, and their uses for food preservation. J Food Sci 79:R1231-R1249
Villagrán C, Castro V (2003) Ciencia indígena de los Andes del Norte de Chile. Biodiversidad. Editorial Universitaria, Santiago

Villagrán C, Romo M, Castro V (2003) Etnobotánica del Sur de los Andes de la Primera Región de Chile: un enlace entre las culturas altiplánicas y las quebradas altas del Loa Superior. Chungara 35:73-124

Wang D, Huang L, Chen S (2013) Senecio scandens Buch.-Ham.: a review on its ethnopharmacology, phytochemistry, pharmacology, and toxicity. J Ethnopharmacol 149:1-23

Wang W, Li M, Li Y (2015) Intervention strategies for reducing Vibrio parahaemolyticus in seafood: a review. J Food Sci 80:R10-R19

Wiegand I, Hilpert K, Hancock RE (2008) Agar and broth dilution methods to determine the minimal inhibitory concentration (MIC) of antimicrobial substances. Nat Protoc 3:163-175

World Health Organization (2014) Cholera 2013. Wkly Epidemiol Rec 31(89):345-356

Yanga $Y$ et al (2011) Chemical and pharmacological research on plants from the genus Senecio. Chem Biodivers 8:13-72

Zardini E (1984) Etnobotánica de compuestas Argentinas con especial referencia a su uso farmacológico. Acta Farm Bonaerense 3:169-194

\section{Submit your manuscript to a SpringerOpen ${ }^{\circ}$ journal and benefit from:}

- Convenient online submission

- Rigorous peer review

- Immediate publication on acceptance

- Open access: articles freely available online

- High visibility within the field

- Retaining the copyright to your article 